\title{
Interferon Treatment of Multiple Sclerosis
}

\author{
Azra Alajbegovic', Dervis Deljo', Salem Alajbegovic², Jasminka Djelilovic-Vranic', Ljubica Todorovic', Merita Tiric-Campara' \\ Neurology Clinic, Clinical Center of Sarajevo University, Sarajevo, Bosnia and Herzegovina' \\ Cantonal Hospital Zenica, Zenica, Bosnia and Herzegovina²
}

Corresponding author: prof. Azra Alajbegović, MD, PhD. Neurology

Clinic. Clinical Center University of Sarajevo. Bolnička 25, 7100

Sarajevo. Bosnia and Herzegovina. Phone: +387 297 357. Fax: +387 297

821. E-mail: azra_alajbegovic@hotmail.com.

\begin{abstract}
ORIGINAL PAPER
SUMMARY

Introduction: In the treatment of Multiple Sclerosis (MS) differ: treatment of relapse, treatment slow the progression of the disease (immunomodulators and immunosuppression), and symptomatic treatment. The aim of this study is to analyze the application of interferon therapy in the treatment of MS-E: Process the disease, patients with multiple sclerosis who have passed the commission for multiple sclerosis at the Neurology Clinic of Clinical Center of Sarajevo University as a reference center for referral to the Commission for multiple sclerosis from the Federal Ministry of Health in 2009 year in terms of total number examined, gender differences, diagnostic tests (MRI, CSF, EP), neurological findings and EDSS scores. Provide a section through the continuous support and education of patients during the introduction Betaferon in therapy with the goal of education for self-use and reduce the incidence of side effects of interferon therapy. Materials and methods: The material for the work they were histories of patients who are registered as patients who have undergone a commission for MS at Department of Neurology, University Clinical Center in Sarajevo. The evaluation was retrospective. It was used a specially designed form, which is usually applied to patients referred to this committee. After the collected material was carried out data processing. The study comprised 34 patients who have undergone a commission of which 16 patients received interferon therapy. Results: In 2009 at the Neurology Clinic CCUS have treated 34 patients who passed the committee for recommendation to interferon therapy ( 25 women and 9 men). The diagnosis of multiple sclerosis is safe based on the criteria of international panel in 2000. EDSS Average score for men was 1.8, 1.9 for women, the total EDSS score was 1.8. The gender ratio is 3:1 in women than in men. Sixteen patients received interferon by the Commission for multiple sclerosis, the Federal Ministry of Health and their therapy was initiated at the clinic. Conclusion: For the period of 2009, a total of 34 patients were examined with multiple sclerosis who received interferon treatment recommendations at the expense of the Federal Solidarity Fund at the Neurology Clinic CCUS Sarajevo. The average EDSS score was 1.8. There were no significant differences in neurological findings between patients who were previously treated with interferon and patients who were waiting for treatment.
\end{abstract}

Key words: Multiple sclerosis, Interferon, treatment.

\section{INTRODUCTION}

In the treatment of Multiple Sclerosis (MS) we can distinguish: the treatment of relapse, treatment for slowing the progression of disease and symptomatic treatment. Interferons belong to the category of treatment that is slowing the progression of the disease or in a group of immunomodulators $(1,2,3)$. These are a group of proteins that normally produce cells in response to viral infection and other incentives. It was first described in 1957 and was named for its ability to interfere (clash) with the viruses. The U.S. Food and Drug Administration (FDA) has approved three forms of interferon beta for treating MS. Beta interferon (IFN-B) has multiple effects on the immune system, including an increase in suppressor cell activity and stopping antigens that stimulate other immune cells (4). Activity of beta-interferon has a network effect in reducing the immune response that is directed against myelin in the central nervous system in people with MS (5). Destruction of myelin (demyelination) causes a slowing of nerve impulses, or stops them and produces the symptoms of MS. Beta interferon reduces the number of relapses in patients with relapsing-remitting form of MS-E (6). The original concept of providing two years of interferon was abandoned, and in today's guide to good practice in the treatment of multiple sclerosis recommended long-term use of interferon with the monitoring of therapeutic efficacy and occurrence of neutralizing antibodies. Interferon beta: reduced number and intensity of relapses, slow the progression of physical disability, reduce the number of active lesions (plaques) on MRI, reducing the need for steroids, and reduces the number of days spent in hospital (7).

Interferon $\beta$-1b in a dose of 8 MIU subcutaneously every other day is the therapy that was applied in patients with $R R$, which in the past two years have had at least two relapses. The most common side effects of interferon: The reaction at the injection site-swelling, redness, discomfort, "flu-like" 
symptoms-fever, chills and shivering. Symptoms usually disappear after the first couple weeks of treatment (8).

FDA in 1996 approved a slightly different form of interferon beta, interferon beta-1a, which is derived from mammalian cells using recombined DNA technology with market name Avonex. To be taken once a week by injection into a muscle. During 1997 Swiss pharmaceutical company, Ares-Serono announced positive results of international clinical trials Rebif and other forms of interferon beta-1a. Rebif is administered by subcutaneous injection three times a week (9).

Treatment with interferon beta-1b (Betaferon) should be initiated under the supervision of a physician, prior to preparing the solution for injection from the contents of the vial with $1.2 \mathrm{ml}$ of solvent, and then $1.0 \mathrm{ml}$ of solution (8.0 MIU) injected subcutaneously every other day. To reduce the risk of necrosis at the injection site aseptic techniques should be used and change the injection site every day. Interferon beta-lb should be kept in a cool place $\left(2-8{ }^{\circ} \mathrm{C}\right)$ before preparing injection solution is stored in the refrigerator where it can be kept for 3 hours. When the patient's course of treatment determine the direction of the nomination for the application of interferon therapy, it is necessary to conduct a comprehensive analysis of all factors affecting the determination, when it comes to determining the type of interferon therapy that will be used in patients with MS, and relationship to other medications used to treat MS.

The goal of this study was to analyze the patients with multiple sclerosis who have passed the commission for multiple sclerosis at the Neurological Clinic, Clinical Center University of Sarajevo (CCUS) for a referral to the Commission for multiple sclerosis by Federal Ministry of Health in 2009 by the total number of examined, gender differences, diagnostic tests (MRI, CSF, EP), EDSS, and give the review of the subgroup that received interferon through the Federal Solidarity Fund in terms of the difference between the groups which is recommended interferon and the subgroup that had received it.

\section{MATERIAL AND METHODS}

In this retrospective, uncontrolled, non randomized study data was taken from medical records of patients at the Neurological Clinic CCUS. In the study participated 34 patients who passed commission of which 16 patients received interferon therapy.

The material for our work was the histories of patients who are registered as patients who were examined by a Commission for multiple sclerosis at the Neurological Clinic CCUS in 2009. For each patient was filled a specially designed questionnaire established by our neighbors.

\section{RESULTS}

Results are presented at Table 1, Table 2, Table 3, Table 4, Table 5, Table 6, Table 7, Table 8, Table 9 and Figure 1, Figure 2, Figure 3 and Figure 4.

Gender structure

During the monitoring period 34 patients received recommendations for therapy with interferon. As for the gender differences from the 34 patients 25 were women and 9 men.

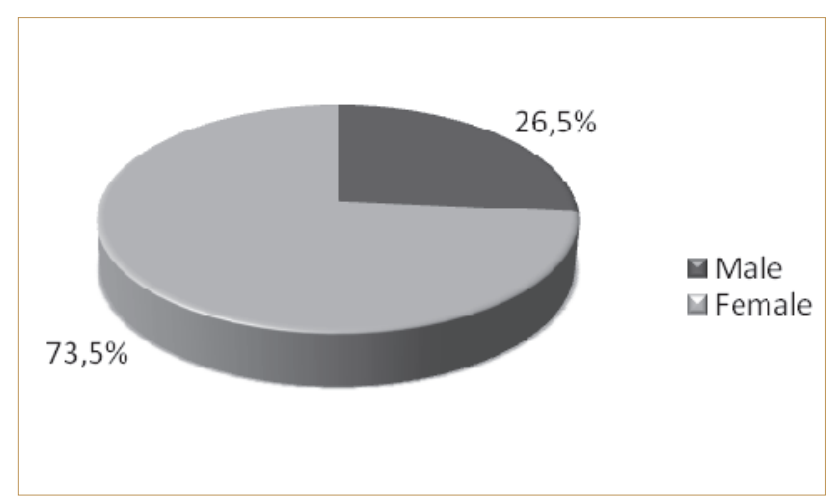

Figure 1. The gender structure of the sample

\begin{tabular}{ccccccc}
\hline \multicolumn{7}{c}{ Age } \\
& N & Mean & $\begin{array}{c}\text { Std. } \\
\text { Deviation }\end{array}$ & $\begin{array}{c}\text { Std. } \\
\text { Error }\end{array}$ & Minimum & Maximum \\
\hline Male & 9 & 33.6667 & 12.14496 & 4.04832 & 17.00 & 48.00 \\
\hline Female & 25 & 34.8800 & 6.98999 & 1.39800 & 17.00 & 53.00 \\
\hline Total & 34 & 34.5588 & 8.46093 & 1.45104 & 17.00 & 53.00 \\
\hline
\end{tabular}

Table 1. Statistical data for the age structure. Anova $=0.133$ $p=0.718$

\begin{tabular}{ccccccc}
\hline \multicolumn{7}{c}{ EDSS score } \\
\hline & N & Mean & $\begin{array}{c}\text { Std. } \\
\text { Deviation }\end{array}$ & $\begin{array}{l}\text { Std. } \\
\text { Error }\end{array}$ & min & max \\
\hline Male & 9 & 1.8056 & 1.22333 & .40778 & .50 & 3.50 \\
\hline Female & 25 & 1.9000 & 1.19896 & .23979 & 1.00 & 6.00 \\
\hline Total & 34 & 1.8750 & 1.18745 & .20365 & .50 & 6.00 \\
\hline
\end{tabular}

Table 2. Statistical data EDSS scores by gender. Anova $=0.041$ $p=0.841$

\begin{tabular}{ccccccc}
\hline \multicolumn{7}{c}{ CSF IgG } \\
\hline & N & Mean & $\begin{array}{c}\text { Std. } \\
\text { Deviation }\end{array}$ & Std. Error & $\min$ & $\max$ \\
\hline Male & 4 & 31.7000 & 19.99300 & 9.99650 & 13.40 & 49.00 \\
\hline Female & 11 & 44.3091 & 23.48840 & 7.08202 & 20.00 & 90.70 \\
\hline Total & 15 & 40.9467 & 22.65041 & 5.84831 & 13.40 & 90.70 \\
\hline
\end{tabular}

Table 3. Statistical data of patients who have positive IgG in CSF, Anova $=0.903 \mathrm{p}=0.359$

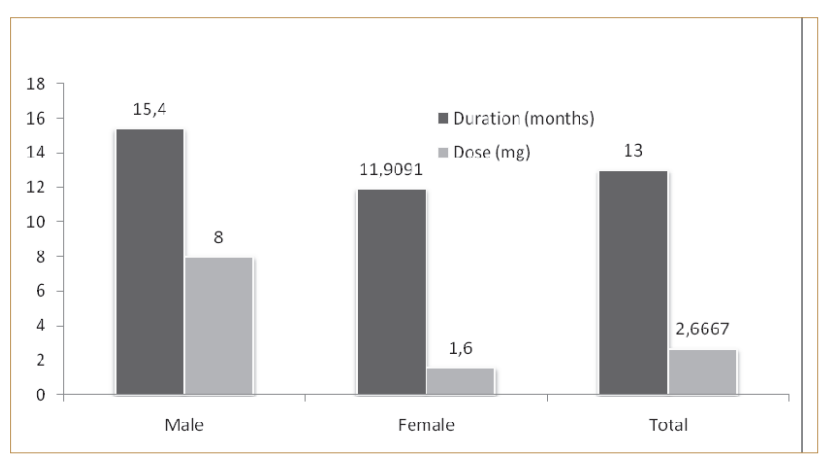

Figure 2. Display of therapy duration and dose of interferon by gender

\section{DISCUSSION}

In our study there were 34 patients, with statistically sibilantly more women.

According to literature data, the ratio of women to men in patients with multiple sclerosis ranges from 2.03:1 to 


\begin{tabular}{ccccccc}
\hline \multicolumn{7}{c}{ Duration of interferon therapy } \\
\hline & N & Mean & $\begin{array}{c}\text { Std. } \\
\text { Deviation }\end{array}$ & $\begin{array}{c}\text { Std. } \\
\text { Error }\end{array}$ & min & max \\
\hline Male & 5 & 15.4000 & 4.92950 & 2.20454 & 12.00 & 24.00 \\
\hline Female & 11 & 11.9091 & 4.18221 & 1.26098 & 2.00 & 18.00 \\
\hline Total & 16 & 13.0000 & 4.57530 & 1.14382 & 2.00 & 24.00 \\
\hline
\end{tabular}

Table 4 Statistical data of interferon the-rapy duration. Anova $=2.155 \mathrm{p}=0.164$

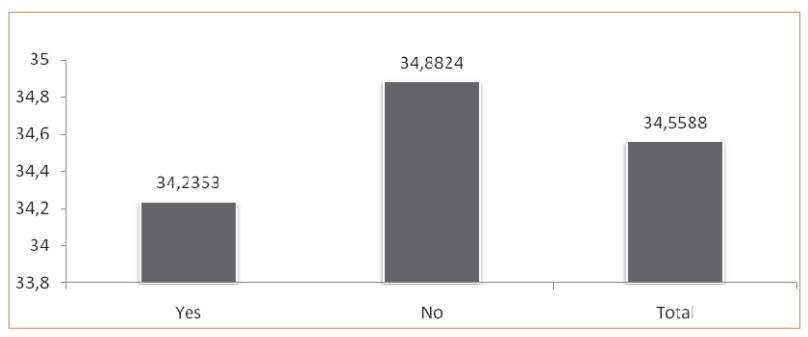

Figure 3. Overview of age according to interferon therapy

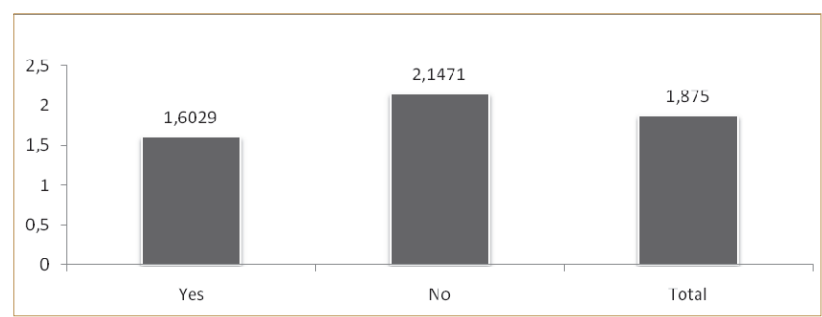

Figure 4 Overview of EDSS score according to treatment with interferon

3.1:1. Van Bockstael in 2004 listed prevalence for women 96.3/100000 inhabitants, for males 41.9/100000 inhabitants in France as the comparative results from our research (10). Hooshmand reported the ratio of women versus men 2.03:1 for patients in Iran (11). Ratio of 3:1 in our material is analogous to data from epidemiological studies of disease distribution between the sexes in the middle risks countries (12). Index of patients and epidemiological studies in our country does not yet exist. There are data for individual clinical centers as a tertiary level of health care where they diagnose and treat multiple sclerosis. The most used diagnostic criteria used by a range of age 10-59 years when the disease occurs, in contrast to earlier studies that used upper limit of the age of 50 years. However, cases of illness are clearly described in childhood and old age. Duquette has found that $2.7 \%$ of cases of the disease in its center began before 16 years of age and for these younger cases was higher proportion of women/men (3:1) (13). The clinical material of Neurology Clinic CCUS for fifteen years showed the youngest patient was 15 , and the oldest 54 years (14). Between January $1^{\text {st }} 2005$ and June $30^{\text {th }} 2005$ Alajbegovic and associates treated at Neurology Clinic in Sarajevo 21 patients with a secure multiple sclerosis (16 women and 5 men), average age 33 years. The youngest patient was 21 years old and the oldest 52 years (16).

The mean age of our patients was 34 years with a SD of 7 years. We can say that the patients in our study had a mean age comparative to the results from the literature. So Sepcic stated that he average life age for disease onset is 25.1 years. It should be noted that an early start according to the majority of authors correlate with the benign course of disease. Beginning after the 36 years of age is considered a negative factor for prognosis in terms of flow and progression $(16,17)$.

No statistically significant differences was found in relation to gender, age and diagnostic tests in the group of patients who were examined by the Commission and have been waiting for the interferon therapy and patients who received interferon therapy for a time period of our research. This can be simply explained by the fact that multiple sclerosis is a disease of time and space, and that all patients have already passed the Commission for interferon therapy, and that the difference was actually in a time when they will begin interferon therapy, since the funds from the Federal Fund which finance interferon therapy are limited. All patients who did not receive interferon therapy were placed on a waiting list. Please note that the EDSS of patients who were waiting for interferon was statistically insignificantly higher as a logical result given that one of the parameters of the ranking list and at the same place at the Commission for multiple sclerosis by the Federal Ministry of Health was EDSS score and age.

If we take this information then we can safely say that we have started to treat our patients during 2009 at an optimal age.

\begin{tabular}{|c|c|c|c|c|c|c|c|c|}
\hline \multicolumn{9}{|c|}{ Overview by duration of interferon therapy } \\
\hline & & $\mathrm{N}$ & Mean & Std. Deviation & Std. Error & Minimum & Maximum & Anova \\
\hline \multirow{3}{*}{ Age } & Yes & 17 & 34.2353 & 7.79045 & 1.88946 & 20.00 & 48.00 & \multirow{3}{*}{$\begin{array}{c}0.048 \\
p=0.827\end{array}$} \\
\hline & No & 17 & 34.8824 & 9.31318 & 2.25878 & 17.00 & 53.00 & \\
\hline & Total & 34 & 34.5588 & 8.46093 & 1.45104 & 17.00 & 53.00 & \\
\hline \multirow{3}{*}{ CSF proteins } & Yes & 9 & .3700 & .10989 & .03663 & .17 & .50 & \multirow{3}{*}{$\begin{array}{c}1.165 \\
p=0.299\end{array}$} \\
\hline & No & 7 & .5043 & .35515 & .13423 & .13 & 1.00 & \\
\hline & Total & 16 & .4288 & .24824 & .06206 & .13 & 1.00 & \\
\hline \multirow{3}{*}{ CSF IgG } & Yes & 8 & 41.2500 & 21.20930 & 7.49862 & 13.40 & 68.30 & \multirow{3}{*}{$\begin{array}{c}0.003 \\
p=0.958\end{array}$} \\
\hline & No & 7 & 40.6000 & 25.92348 & 9.79815 & 15.40 & 90.70 & \\
\hline & Total & 15 & 40.9467 & 22.65041 & 5.84831 & 13.40 & 90.70 & \\
\hline \multirow{3}{*}{ EDSS score } & Yes & 17 & 1.6029 & 1.01957 & .24728 & .50 & 3.50 & \multirow{3}{*}{$\begin{array}{r}1.830 \\
p=0.168\end{array}$} \\
\hline & No & 17 & 2.1471 & 1.30820 & .31729 & 1.00 & 6.00 & \\
\hline & Total & 34 & 1.8750 & 1.18745 & .20365 & .50 & 6.00 & \\
\hline
\end{tabular}

Table 5 Statistical data review of age, EDSS score and CSF according to therapy with interferon 
MRI by gender

\begin{tabular}{|c|c|c|c|c|c|}
\hline & & & \multicolumn{2}{|c|}{ Gender } & \multirow{2}{*}{ Total } \\
\hline & & & Male & Female & \\
\hline \multirow{18}{*}{ MRI } & \multirow{2}{*}{ Demyelinating changes } & $\mathrm{N}$ & 0 & 2 & 2 \\
\hline & & $\%$ & .0 & 8.0 & 5.9 \\
\hline & \multirow{2}{*}{ Hyper signal zones } & $\mathrm{N}$ & 0 & 2 & 2 \\
\hline & & $\%$ & .0 & 8.0 & 5.9 \\
\hline & \multirow{2}{*}{ Cortex hypotrophy } & $\mathrm{N}$ & 1 & 0 & 1 \\
\hline & & $\%$ & 11.1 & .0 & 2.9 \\
\hline & \multirow{2}{*}{ Lesions } & $\mathrm{N}$ & 0 & 1 & 1 \\
\hline & & $\%$ & .0 & 4.0 & 2.9 \\
\hline & \multirow{2}{*}{ Papilloma } & $\mathrm{N}$ & 0 & 1 & 1 \\
\hline & & $\%$ & .0 & 4.0 & 2.9 \\
\hline & \multirow{2}{*}{ Plaques } & $\mathrm{N}$ & 7 & 9 & 16 \\
\hline & & $\%$ & 77.8 & 36.0 & 47.1 \\
\hline & \multirow{2}{*}{ Altered signal } & $\mathrm{N}$ & 1 & 8 & 9 \\
\hline & & $\%$ & 11.1 & 32.0 & 26.5 \\
\hline & \multirow{2}{*}{ Not done } & $\mathrm{N}$ & 0 & 2 & 2 \\
\hline & & $\%$ & .0 & 8.0 & 5.9 \\
\hline & \multirow{2}{*}{ Total } & $\mathrm{N}$ & 9 & 25 & 34 \\
\hline & & $\%$ & 100.0 & 100.0 & 100.0 \\
\hline
\end{tabular}

Table 6. Statistical presentation of MRI according to gender.. $\mathrm{X} 2=9.203 \mathrm{DF}=7 \mathrm{p}=0.238$

Evoked potentials by gender

\begin{tabular}{|c|c|c|c|c|c|}
\hline & & & \multicolumn{2}{|c|}{ Gender } & \multirow{2}{*}{ Total } \\
\hline & & & Male & Female & \\
\hline \multirow{12}{*}{ EP } & \multirow{2}{*}{ Borderline } & $\mathrm{N}$ & 4 & 8 & 12 \\
\hline & & $\%$ & 44.4 & 32.0 & 35.3 \\
\hline & \multirow{2}{*}{ Slightly altered } & $\mathrm{N}$ & 1 & 4 & 5 \\
\hline & & $\%$ & 11.1 & 16.0 & 14.7 \\
\hline & \multirow{2}{*}{ Normal } & $\mathrm{N}$ & 0 & 1 & 1 \\
\hline & & $\%$ & .0 & 4.0 & 2.9 \\
\hline & \multirow{2}{*}{ Pathological } & $\mathrm{N}$ & 2 & 7 & 9 \\
\hline & & $\%$ & 22.2 & 28.0 & 26.5 \\
\hline & \multirow{2}{*}{ Altered } & $\mathrm{N}$ & 2 & 3 & 5 \\
\hline & & $\%$ & 22.2 & 12.0 & 14.7 \\
\hline & \multirow{2}{*}{ Not done } & $\mathrm{N}$ & 0 & 2 & 2 \\
\hline & & $\%$ & .0 & 8.0 & 5.9 \\
\hline & \multirow{2}{*}{ Total } & $\mathrm{N}$ & 9 & 25 & 34 \\
\hline & & $\%$ & 100.0 & 100.0 & 100.0 \\
\hline
\end{tabular}

Table 7. Statistical presentation of EP according to gender. $\mathrm{X} 2=2.032 \mathrm{DF}=5 \quad \mathrm{p}=0.845$

Committee for multiple sclerosis at the Federal Ministry of Health at its first session in 2005 set the criteria for the treatment of multiple sclerosis with interferon. The criteria are connected to guidelines for the treatment of multiple sclerosis by American and European groups for the treatment of patients.

The criteria were: age of 18-55 years, certainly the diagnosis of multiple sclerosis, the absence of mental disorders, the absence of pregnancy and the EDSS score.

Within the diagnostic criteria finding of intrathecal synthesis of immunoglobulins, IgG is a crucial test. Proteins in cerebrospinal fluid were positive in $47 \%$ of our respondents.
Neurological findings according to interferon therapy

\begin{tabular}{|c|c|c|c|c|}
\hline & & \multicolumn{2}{|c|}{ Interferon } & \multirow{2}{*}{ Total } \\
\hline & & Yes & No & \\
\hline \multirow{2}{*}{ Hemiparesis } & $\mathrm{N}$ & 6 & 3 & 9 \\
\hline & $\%$ & 23.1 & 9.7 & 15.8 \\
\hline \multirow{2}{*}{ Quadriparesis spastica } & $\mathrm{N}$ & 2 & 8 & 10 \\
\hline & $\%$ & 7.7 & 25.8 & 17.5 \\
\hline \multirow{2}{*}{ Larmitte sign } & $\mathrm{N}$ & 1 & 1 & 2 \\
\hline & $\%$ & 3.9 & 3.2 & 3.5 \\
\hline \multirow{2}{*}{ Nystagmus } & $\mathrm{N}$ & 6 & 2 & 8 \\
\hline & $\%$ & 23.1 & 6.4 & 14.1 \\
\hline \multirow{2}{*}{ Paresis facialis } & $\mathrm{N}$ & 1 & 3 & 4 \\
\hline & $\%$ & 3.9 & 9.7 & 7.0 \\
\hline \multirow{2}{*}{ Increased muscle reflexes } & $\mathrm{N}$ & 5 & 7 & 12 \\
\hline & $\%$ & 19.2 & 22.6 & 21.1 \\
\hline \multirow{2}{*}{ Romberg } & $\mathrm{N}$ & 3 & 3 & 6 \\
\hline & $\%$ & 11.5 & 9.7 & 10.5 \\
\hline \multirow{2}{*}{ Babinski } & $\mathrm{N}$ & 1 & 3 & 4 \\
\hline & $\%$ & 3.9 & 9.7 & 7.0 \\
\hline \multirow{2}{*}{ Normal } & $\mathrm{N}$ & 1 & 1 & 2 \\
\hline & $\%$ & 3.9 & 3.2 & 3.5 \\
\hline \multirow{2}{*}{ Total } & $\mathrm{N}$ & 26 & 31 & 57 \\
\hline & $\%$ & 100.0 & 100.0 & 100.0 \\
\hline
\end{tabular}

Table 8. Statistical presentation of neurological findings by interferon therapy. $X 2=15.533 \mathrm{DF}=8 \mathrm{p}=0.0173$

MRI according to interferon therapy

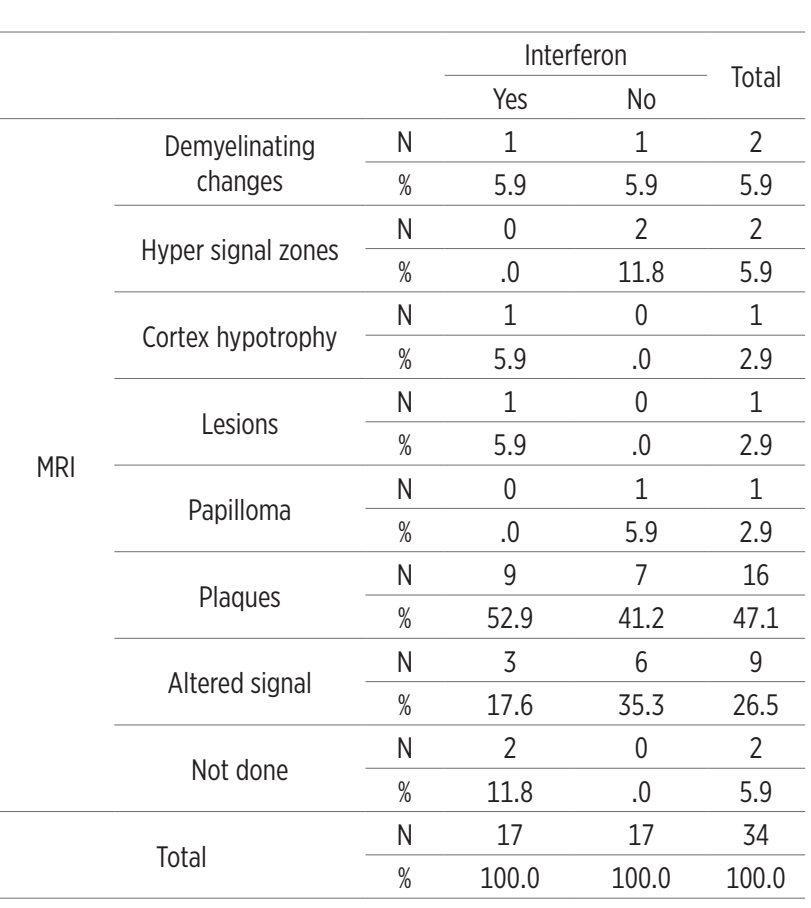

Table 9. Statistical presentation of MRI by interferon therapy. $\mathrm{X} 2=18.250 \quad \mathrm{DF}=7 \quad \mathrm{p}=0.0031$

For other subjects we do not have data on the findings of the lumbar puncture. This explains the fact that some of the patients were previously hospitalized or diagnostic relevant tests were done in other centers. 
EP according to interferon therapy

\begin{tabular}{|c|c|c|c|c|c|}
\hline & & & \multicolumn{2}{|c|}{ Interferon } & \multirow{2}{*}{ Total } \\
\hline & & & Yes & No & \\
\hline \multirow{12}{*}{ EP } & \multirow{2}{*}{ Borderline } & $\mathrm{N}$ & 4 & 8 & 12 \\
\hline & & $\%$ & 23.5 & 47.1 & 35.3 \\
\hline & \multirow{2}{*}{ Slightly altered } & $\mathrm{N}$ & 3 & 2 & 5 \\
\hline & & $\%$ & 17.6 & 11.8 & 14.7 \\
\hline & \multirow{2}{*}{ Normal } & $\mathrm{N}$ & 0 & 1 & 1 \\
\hline & & $\%$ & .0 & 5.9 & 2.9 \\
\hline & \multirow{2}{*}{ Pathological } & $\mathrm{N}$ & 4 & 5 & 9 \\
\hline & & $\%$ & 23.5 & 29.4 & 26.5 \\
\hline & \multirow{2}{*}{ Altered } & $\mathrm{N}$ & 4 & 1 & 5 \\
\hline & & $\%$ & 23.5 & 5.9 & 14.7 \\
\hline & \multirow{2}{*}{ Not done } & $\mathrm{N}$ & 2 & 0 & 2 \\
\hline & & $\%$ & 11.8 & .0 & 5.9 \\
\hline & \multirow{2}{*}{ Total } & $\mathrm{N}$ & 17 & 17 & 34 \\
\hline & & $\%$ & 100.0 & 100.0 & 100.0 \\
\hline
\end{tabular}

Table 10. Statistical presentation of EP by interferon therapy. $\mathrm{X} 2=16.444 \quad \mathrm{DF}=5 \quad \mathrm{p}=0.0026$

Timely diagnosis of multiple sclerosis has many direct benefits for the patients: to remove the uncertainty of diagnosis, to identify candidates for therapy, provides guidelines for disease modifying therapy and significantly improve quality of patient's life.

MRI and CSF are key laboratory tests, their sensitivity increases over time.

All other laboratory tests are additional. Para clinical tests included MRI, CSF (cerebrospinal fluid) and visually evoked potential (VEP). CSF parameters include a recommendation to use more sensitive methods to determine oligoclonal ribbons and demonstrate intrathecal IgG immunoglobulins synthesis (18).

All our patients had definitely been diagnosed with multiple sclerosis.

Average EDSS score for men was 1.8056, for women 1.9, and a total EDSS score of 1.875. EDSS score was used to monitor disease progression and monitoring the effects of therapies to stop disease progression, which means that patients treated with immunomodulators had lower score and level of disability.

The first prospective, multicenter, randomized study to compare the results of the effectiveness of interferon beta$1 \mathrm{~b}$ (8MIU) every other day subcuteously and interferon beta-1a (6 MIU) once a week was the INCOMIN study (Durel 2002) (19).

Criteria for inclusion implied RRMS patients with a Kurtzke EDSS score of 1-3.5, with two or more exacerbations in the past two years. Study included 188 patients aged 1850 years. Our EDSS findings are comparable to the results of this study.

The first controlled study that demonstrated the effectiveness of systemically administered interferon beta has started in 1988, which was double-blind, placebocontrolled, included patients with RRMS with EDSS 0-5.5, and with at least two exacerbations in the previous two years. Included were 372 patients, divided into three groups, one receiving placebo, the other 1.6 MIU of interferon beta-lb, and the third 8.0 MIU of interferon beta-lb, subcutaneously every other day (IFNB Multiple Sclerosis Study Group, 1993) (20).

The results of this study after two years showed that patients who received interferon beta in dose of 8.0 MIU had significant reduction, for almost $1 / 3$ in the annual exacerbation number in comparison with the placebo group. The median time to occurrence of the first exacerbation was significantly prolonged, about two times longer than in the group that received 8 MIU compared to the placebo group. Significantly was reduced the number of hospital days and the need for administration of steroids.

Significantly delayed exacerbations time in people with RRMS 2 and 3 years after starting the treatment with Betaferon, was more pronounced in those who received 8 MIU of interferon $\beta-1 b$ (21).

Currently in the world are in progress more than 50 studies in the $2^{\text {nd }}$ or $3^{\text {rd }}$ phase clinical trials with different drugs for the treatment of patients suffering from multiple sclerosis.

In the guides for MS therapy still the first line of choice are interferons in the onset of illness.

Since 2005 at the expense of the Federal Solidarity Fund were treated 117 patients. In the Federation of Bosnia and Herzegovina, we can say that the percentage of patients who are optimally treated is less than $10 \%$. The fact is that the diagnostic tests in the context of the world's barometer of treatment of patients with multiple sclerosis. Hopefully those therapeutic guidelines will go in this direction (21).

\section{CONCLUSION}

For the period of year 2009 a total of 34 patients were examined with multiple sclerosis who received a recommendation for therapy with interferon sponsored by the Federal Solidarity Fund at the Neurology Clinic CCUS as one of the clinics for recommendation of immunomodulatory therapy.

In the sample there were significantly more female patients. There was no statistically significant difference in the EDSS score between male and female patients. We did not find statistically significant difference in the findings of MRI, CSF and evoked potentials between male and female patients.

Diagnostic criteria for multiple sclerosis were met by all candidates for interferon therapy.

The average EDSS score was 1.8.

From the total number of 34 patients who were examined by the commission 16 patients received interferon therapy, others were placed on the waiting list.

There were no significant differences in distribution between the sexes, age, diagnostic parameters, neurological symptomatology and neurological syndromes among patients who received interferon, and patients who were waiting for treatment.

The treatment of patients with interferon in our study shows that $47 \%$ of patients who were examined by the Commission received interferon therapy in a timely manner, or in early stage disease when immunomodulators should be given and when they are most effective. We believe that a 
greater pressure is needed on health insurance funds in order that patients suffering from multiple sclerosis start treatment with immunomodulators time, delayed the progression of the disease, significantly improve the quality of life and make it a longer period of productive life and social functioning, so in essence put less burden on health funds insurance.

\section{Conflict of interest: none declared.}

\section{REFERENCES}

1. Azra Kurtović-Alajbegović i saradnici:MULTIPLA SKLEROZA. Magistrat Sarajevo, Sarajevo decembar 2005.

2. Kantardžić Dželaludin i saradnici:Klinička neurologija. Svjetlost, Sarajevo 2001.

3. Multiple sclerosis: Hope through research. National Institute of Neurological Disorders and Stroke. http://www.ninds.nih. gov/disorders/multiple_sclerosis/detail_multiple_sclerosis. htm. Accessed Oct. 1, 2008.

4. Olek MJ. Epidemiology, risk factors and clinical features of multiple sclerosis in adults. http://www.uptodate.com/home/ index.html. Accessed Oct. 1, 2008.

5. Noseworthy JH, et al. Multiple sclerosis. In: Goetz CG, et al. Textbook of Clinical Neurology. 3rd ed. Philadelphia, Pa.: Saunders Elsevier; 2007. http://www.mdconsult. com/das/book/body/106141078-3/0/1488/405.html\#4-u1 .0-B978-1-4160-3618-0..10048-7-s0030_4069. Accessed Oct. 1, 2008.

6. Fatigue. National Multiple Sclerosis Society. http://www. nationalmssociety.org/about-multiple-sclerosis/symptoms/ fatigue/index.aspx. Accessed Oct. 2, 2008.

7. Olek MJ. Diagnosis of multiple sclerosis in adults. http:// www.uptodate.com/home/index.html. Accessed Oct. 2, 2008.

8. Neurological diagnostic tests and procedures. National Institute of Neurological Disorders and Stroke. http:// www.ninds.nih.gov/disorders/misc/diagnostic_tests.htm. Accessed Oct. 1, 2008.

9. You can ... maintain good nutrition. National Multiple Sclerosis Society. http://www.nationalmssociety.org/living-with-multiple-sclerosis/you-can/maintain-good-nutri- tion/index.aspx. Accessed Oct. 2, 2008.

10. Van Bockstael, S Gosselin,S.Vukusic,C Confavreux. Prevalence of Multiple Sclerosis in Franch farmers: a notionwide survey.Multiple Sclerosis Volumen 10.Suplement 2, September 2004: 156.

11. Hooshmand F, Jangouk R. study of 1714 Iranian multiple sclerosis patients.Multiple sclerosis Vol.10 (suppl2):september 2004.157.

12. Đelilović J, Alajbegović A,Suljić E et al. Multiple sclerosis at the Neurological Clinic in Sarajevo before and after the war,1.Internacionalna konferencija o multiploj sklerozi u Dubrovniku,Neurol.Croat. 2001, Vol.50,Suplement,(1):40.

13. Duquette $\mathrm{P}$ et al. Multiple sclerosis in childhood:clinical profile in 125 patientsJournal of Pediatric,1997,111:359-363.

14. A.Guseo. 66 years of multiple sclerosis in Feje'r country, West Hungary. Multiple Sclerosis Vol.10 (2) September 2004:156.

15. Alajbegović i saradnici. Tretman multiple skleroze viskim dozama kortikosterida na Neurološkoj klinici KCU Sarajevo.Simpozijum o MS Varaždinske Toplice 3004.Zbornik radova 23-28.

16. Sepčić J et al. Multiple sclerosis cluster in Gorski Kotar,Croatia,Yugoslavia, In: Battaglia Med. Multiple sclerosis research.1989,Amsterdam,Elsevier:165-169.

17. Sepčić J et al. Nutritional factors and multiple sclerosis in Gorski Kotar, Croatia, Neuroepidemiology,1993,12:234-240.

18. Poser CM,Paty DW, Scheinberg L et alt. New diagnostic criteria for multiple sclerosis: guidelines for research protocols. Ann Neurol 1983;13:227-231.

19. Durelli,L. Verdun E, Barbero P. et al.(2002)Every-other day interferon beta-1b versus oce-weekly interferon beta.1a for multiple sclertosis: Results of a 2-year prospective randomised multi-center study(INCOMIN).The Lancet 359,1453-60

20. IFNB Multipler Sclerosis Study Group(2003) Interferon -1b is effective in relapsing-remitting multiple sclerosis.I. Clinical results of a multicenter, randomized, double-blind, placebo controlled trial. Neurology 43, 655-66

21. Jacobs LD, Beck RW, Simon JH, et al, and the CHAMPS Study Group. Intramuscular interferon beta-1a therapy initiated during a first demyelinating event in multiple sclerosis. N Engl J Med 2000 Sep 28;343:898-904.

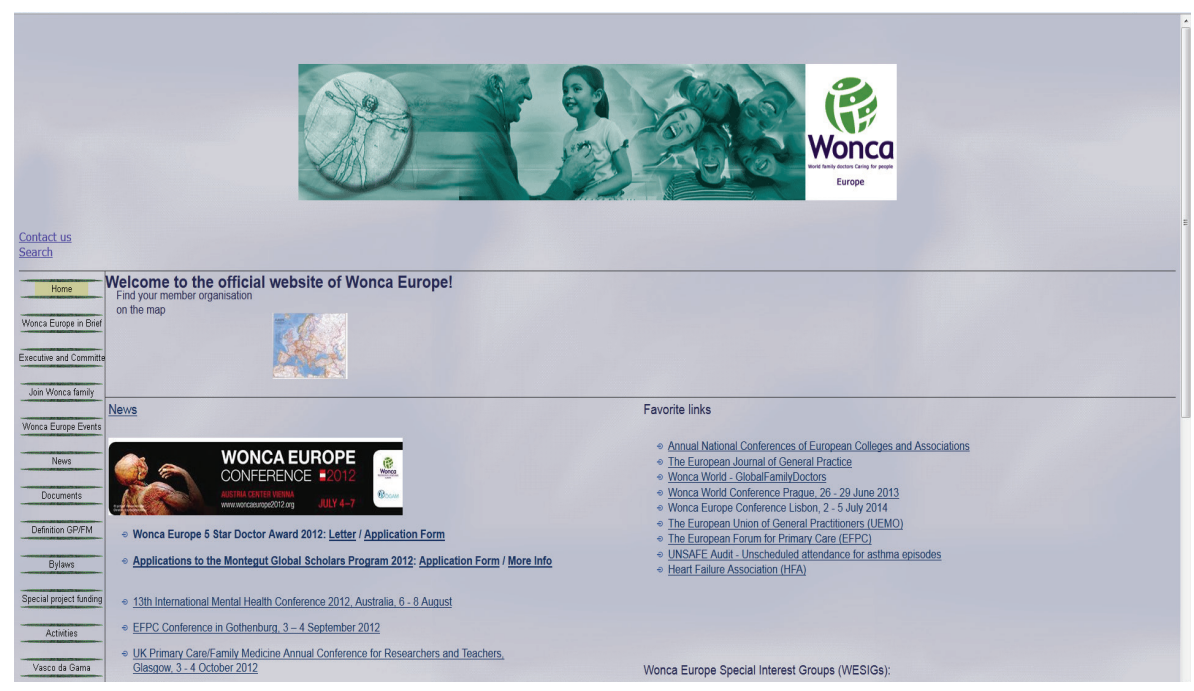

